\title{
THE INFLUENCE OF FUNCTION, FORM AND STRUCTURE ON THE SPATIAL HIERARCHY OF THE TAWANG RAILWAY STATION IN SEMARANG
}

\author{
${ }^{1}$ Beni Adi Santoso. ${ }^{2}$ Dr. Ir. Bachtiar Fauzy, M.T. \\ ${ }^{1}$ Student in the Bachelor's (S-1) Study Program in Architecture at \\ Parahyangan Catholic University \\ ${ }^{2}$ Senior lecturer in the Bachelor's (S-1) Study Program in Architecture at \\ Parahyangan Catholic University
}

\begin{abstract}
Dutch East Indies Empire architecture in Indonesia must be preserved as a result of acculturation between a foreign culture and a local one. The century-old Tawang Railway Station in Semarang has been hit by annual rob floods and has undergone somerenovation, but the latter has made the impact of reducing the architectural values of "Indies" style in its features. This research study may deepen understanding of this type of colonial architecture, exploring its application to this railway station. Furthermore, an in-depth analysis determines how function, form and structure have affected the spatial hierarchy of this railway station. This study is descriptive, analytical and interpretative, employing theories dealing with archetypes, ordering principles and Dutch East Indies Empire architecture. After data collection, the analysis compares these theories with the object of study. The findings indicate that this station has indeed applied the concept of the Dutch colonial style, starting from the context of the local area to the building elements, except for the floor. At present, the latter has already been changed in its entirety, from the initial building stage to its current state, where the specific "Indies" character can no longer be discerned. The zenith of hierarchy can be observed in the main lobby whose function is to receive visitors in its cube-shaped space similar to the Sokoguru (central Javanese pillar) and the cupola not found in any other part of the building. The building mass of the station is symmetrical in keeping with its typical "Indies" character, but the function of the interior space is asymmetrical. This shows the importance of achieving a high degree of spatial efficiency to make the activities run smoothly and effectively.
\end{abstract}

Keywords: Hierarchy, Space, Dutch East Indies Empire Architecture, Semarang's Tawang Railway Station

\section{PENGARUH FUNGSI, BENTUK, DAN STRUKTUR TERHADAP HIERARKI RUANG PADA STASIUN SEMARANG TAWANG DI SEMARANG}

\author{
${ }^{1}$ Beni Adi Santoso. ${ }^{2}$ Dr. Ir. Bachtiar Fauzy, M.T. \\ ${ }^{1}$ Mahasiswa S1 Program Studi Arsitektur Universitas Katolik Parahyangan. \\ ${ }^{2}$ Dosen Pembimbing S1 Program Studi Arsitektur Universitas Katolik Parahyangan.
}

\begin{abstract}
Abstrak-Arsitektur Indis di Indonesia sebagai suatu hasil akulturasi budaya asing dengan budaya lokal harus dilestarikan. Stasiun Semarang Tawang di Semarang yang telah berusia 100 tahun telah mengalami banjir rob

${ }^{1}$ Corresponding Author: beni.santoso94@gmail,com
\end{abstract}


tahunan dan renovasi namun renovasi tersebut berdampak pada semakin berkurangnya nilai-nilai arsitektur indis pada bangunannya. Penelitian ini dilakukan untuk mendalami pengertian arsitektur indis dan mencari tahu penerapan konsep arsitektur indis pada Stasiun Semarang Tawang. Lebih dalam lagi, penelitian juga menganalisis bagaimana fungsi, bentuk, dan struktur dapat mempengaruhi hierarki ruang pada Stasiun Semarang Tawang.Penelitian bersifat deskriptif, analitis, dan interpretatif dan dengan menggunakan teori archetype, ordering principle, dan teori arsitektur indis. Setelah data terkumpul analisis dilakukan dengan membandingkan teori dengan objek. Temuan yang didapat adalah Stasiun Tawang menerapkan konsep arsitektur indis mulai dari konteks kawasan hingga elemen bangunannya kecuali pada lantai. Saat ini lantai sudah mengalami perubahan total dari sejak dibangun sehingga tidak terlihat lagi karakter arsitektur indisnya. Hierarki tertinggi ada pada lobi utama yang fungsinya menerima pengunjung dengan bentuk ruang kubus dan memilikki sktruktur serupa soko guru dan cupola yang tidak ditemukan pada bagian lain bangunan. Massa bangunan stasiun simetris sesuai karakter arsitektur indis namun pada fungsi ruang dalamnya tidak simetris. Hal ini menunjukkan pentingnya efisiensi pencapaian ruang agar kegiatan berjalan efektif.

Kata Kunci: Hierarki, Ruang, Arsitektur Indis, Stasiun Semarang Tawang

\section{PENDAHULUAN}

Kebudayaan Indis merupakan hasil akulturasi kebudayaan asing dengan kebudayaan lokal. Dalam dunia arsitektur, hasil dari kebudayaan ini adalah arsitektur indis yang patut dilestarikan saat ini. Menurut Fauzy (2003) kearifan lokal membentuk karakter arsitektur sebagai akibat akulturasi. Bangunan buatan Belanda pun juga akan memunculkan kearifan lokal setempat. Sejarah kolonialisme tidak terlepas dari peran kereta api sebagai pemersatu antar daerah di Jawa. Awalnya ide angkutan kereta api digunakan untuk mengangkut hasil bumi setelah tanam paksa diberlakukan oleh Van der Bosch tahun 1825-1830. Stasiun Semarang Tawang merupakan salah satu bangunan kolonial yang masih aktif digunakan. Walaupun sudah ditetapkan menjadi bangunan cagar budaya, belum ada pembenahan untuk mengembalikan wujudnya seperti di masa lalu. Kereta api pertama dibangun tahun 1867 di Semarang dengan rute Semarang - Tanggung oleh NISM (Nederlands-Indische Spoorweg Maatchappij). Akhir-akhir ini, renovasi Stasiun Tawang berdampak pada semakin berkurangnya nilai-nilai arsitektur indis pada bangunannya sehingga diperlukan adanya pembahasan lebih dalam mengenai keunikan konsep arsitektur Indis yang diterapkan pada Stasiun Semarang Tawang.

Masalah yang akan diteliti berkaitan dengan penerapan arsitektur indis pada stasiun Tawang. Stasiun Tawang sebagai objek penelitian berlokasi di Jalan Taman Tawang 1, kawasan Kota Lama Semarang. Stasiun ini merupakan stasiun terbesar di Semarang dan sekitarnya (Figur 1). Penelitan ini juga dilakukan dengan menganalisis bagaimana fungsi, bentuk, dan struktur berpengaruh terhadap terciptanya hierarki ruang pada Stasiun Semarang Tawang. 


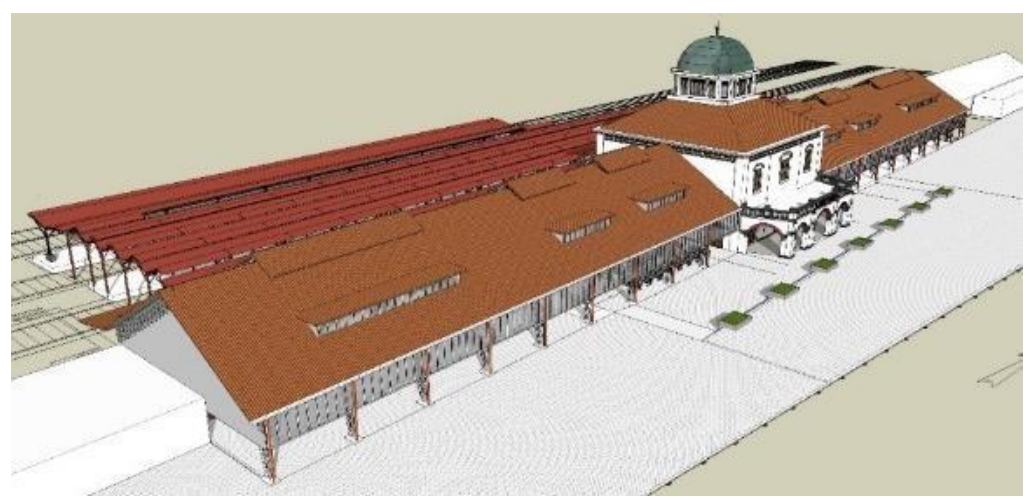

Figur 1. Aerial View Stasiun Tawang

Penelitian dilakukan demi menambah kajian teori akademik mengenai arsitektur indis dan arsitektur stasiun pada masa kolonial. Selain itu penelitian ini juga akan berguna dalam memaparkan pentingnya peran Stasiun Tawang sebagai arsitektur indis di Kota Lama Semarang dan berupaya untuk melestarikannya, Pada akhrnya diharapkan penelitian ini dapat menjadi dasar pertimbangan konservasi agar tidak mengurangi karakter arsitektur indis pada bangunan tersebut.

Penelitian bersifat deskriptif, analitis, dan interpretatif. Teori yang digunakan adalah teori archetype oleh Evensen, ordering principle, dan teori arsitektur indis. Setelah data terkumpul analisis dilakukan dengan menilai objek berdasarkan teori. Pada akhirnya kesimpulan yang menjawab pertanyaan penelitian ditarik sehingga penulis dapat mengetahui kualitas objek dan relevansi nya terhadap referensi.

Tabel 1. Data Umum Stasiun Semarang Tawang

\begin{tabular}{|l|l|}
\hline \multicolumn{2}{|c|}{ itasiun Semarang Tawang Semarang } \\
\hline Lokasi & Jl. Taman Tawang 1, Semarang \\
\hline Tahun Pembangunan & 29 April 1911 - 1 Juni 1914 \\
\hline Arsitek & Mr. Sloth-Blauwboer \\
\hline Luas Lahan & $27310 \mathrm{~m}^{2}$ \\
\hline Luas Bangunan Utama & $5300 \mathrm{~m}^{2}$ \\
\hline Status Kepemilikan & PT. Kereta Api Indonesia (Persero) \\
\hline
\end{tabular}

\section{ANALISA}

\subsection{PENERAPAN KONSEP ARSTITEKTUR INDIS PADA STASIUN TAWANG}

\subsubsection{PERLETAKAN BANGUNAN TERHADAP KAWASAN}

Stasiun Tawang berada pada lokasi yang strategis yaitu di kota lama. Pada masa kolonial daerah ini merupakan permukiman Belanda (Purwanto, 2005). Lokasi ini dinilai strategis karena membuat stasiun Tawang dapat berfungsi secara efektif yaitu dekat dengan permukiman untuk angkutan orang dan dekat dengan pelabuhan untuk angkutan barang. Akses ke stasiun juga mudah karena berada di pinggir jalan arteri. Hal ini sesuai dengan teori bangunan kolonial 
diletakkan di posisi strategis untuk memudahkan kegiatan pemerintah Hindia Belanda (Figur 2). Stasiun Tawang menjadi bangunan yang menjulang karena bangunan sekitarnya adalah permukiman warga dan pertokoan. Di depan stasiun juga terdapat ruang terbuka yaitu sebuah polder yang cukup besar sehingga orang yang lewat kawasan ini langsung mengetahui bangunan ini penting. (Figur 3)

Posisi strategis yang digunakan stasiun Tawang justru bukan di tengah kota melainkan tepi kota tua dikarenakan sebagai bangunan stasiun akan lebih mudah jika tidak ada rel kereta yang melintang di tengah permukiman. Selain itu stasiun akan menjadi lebih dekat dengan kawasan pelabuhan untuk bongkar muat barang.

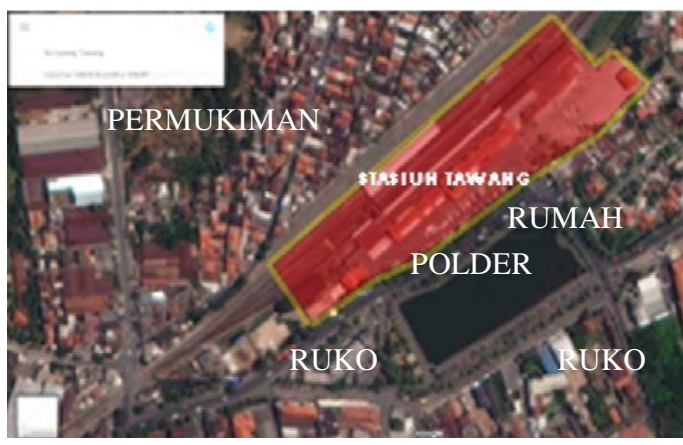

Figur2.Stasiun Tawang Berada Pada Lokasi Strategis

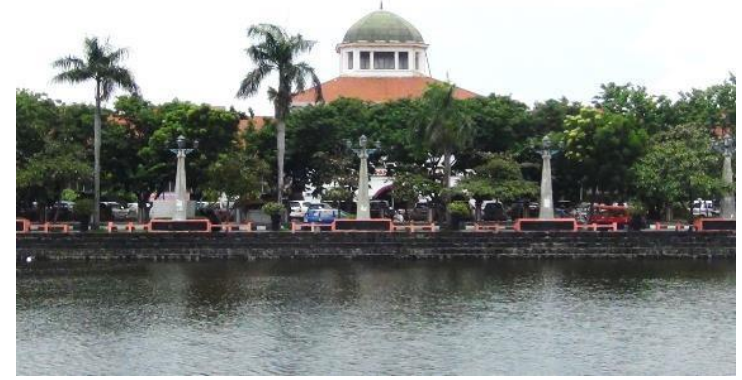

Figur 3. Stasiun Tawang terlihat megah dari seberang polder

\subsubsection{RELASI TAPAK DAN BANGUNAN}

Tapak Stasiun Tawang cukup besar sehingga bangunan asli ditempatkan di tengah tapak di samping bangunan tambahan baru. Pada jaman dahulu tapak yang luas biasanya dimanfaatkan untuk taman. Pada Stasiun Tawang tapak dimanfaatkan untuk lahan parkir. Bangunan menghadap ke arah tenggara dengan maksud mengurangi paparan sinar matahari langsung pada seluruh fasad. Sebenarnya faktor lain yang juga menjadi penentu adalah jalur rel kereta. Jalur kereta yang harus seefektif mungkin menghubungkan tempat-tempat strategis menjadi penentu orientasi bangunan stasiun. Jadi orientasi stasiun merupakan hasil pertimbangan faktor arah mata angin dan arah jalur rel. Pagar pembatas depan dibuat tidak masif sehingga orang umum bisa melihat langsung bangunan dan dapat menarik pengunjung (Figur 4). 


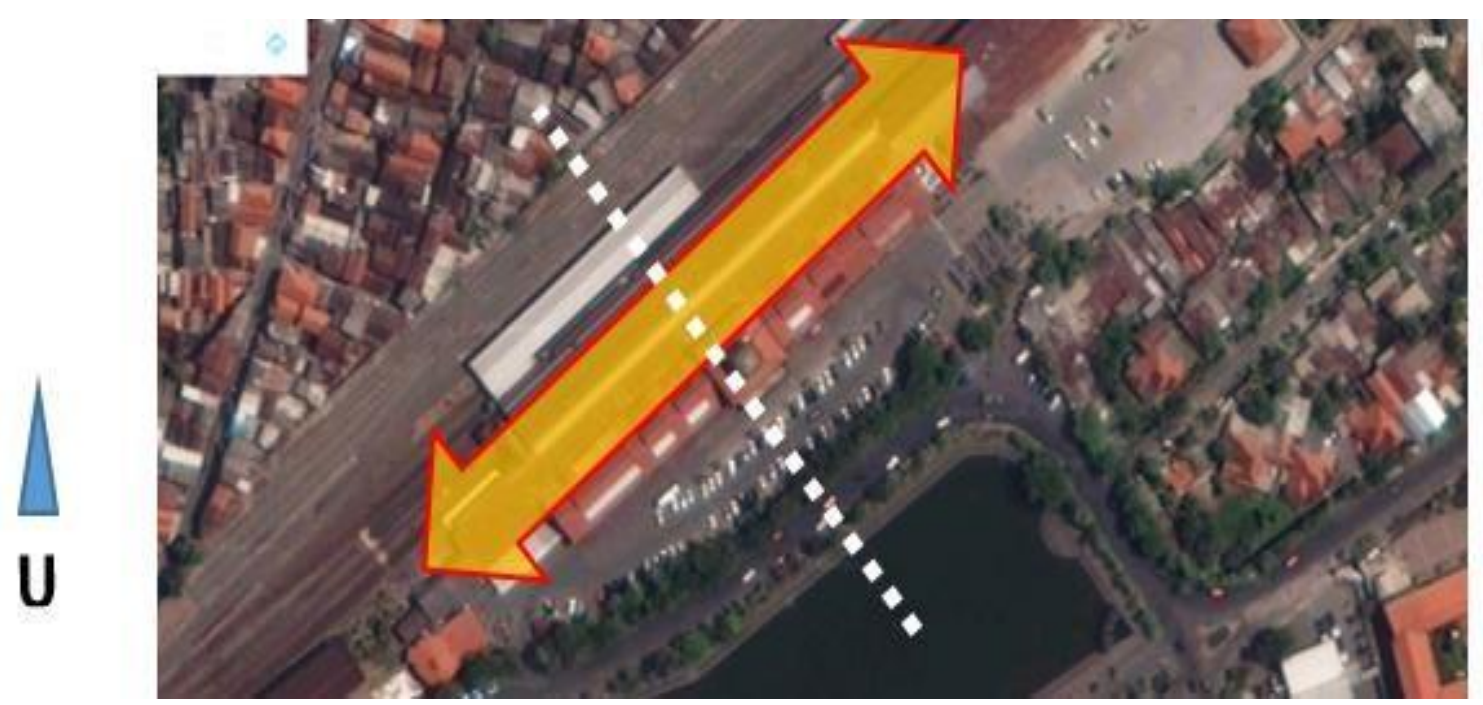

Figur 4. Perletakkan Massa Bangunan Stasiun Tawang di Tengah Tapak

\subsubsection{BENTUK MASSA BANGUNAN}

Bentuk dan massa bangunan stasiun memanjang mengikuti arah rel kereta. Massa bangunan sederhana dan bagian atap mendominasi tampak bangunan. Tipologi bangunan stasiun dibawa oleh Belanda karena di nusantara sebelumnya tidak mengenal stasiun namun tetap ada beberapa penyesuaian bentuk massa terhadap iklim tropis. Pada Stasiun Tawang bentuk dasar massa bangunan geometris kubus dan balok. Penataan massa bangunan menunjukkan hierarki yang jelas. Bagian lobi utama yang berada di tengah dan memilikki massa terbesar merupakan bagian yang memilikki hierarki tertinggi untuk merepresentasikan Stasiun Tawang (Figur 5).

Pada Stasiun Tawang bentuk dasar massa bangunan merupakan bentuk geometris kubus dan balok. Atap tajug pada lobi utama memberi bentuk limas segiempat. Atap pelana pada bangunan sampingnya memberi bentuk prisma segitiga (Figur 6). Bentuk bangunan tidak mengalami banyak transformasi sehingga tidak banyak detil-detil yang berisiko rusak saat berhadapan dengan iklim tropis setempat. Penataan massa bangunan menunjukkan hierarki yang jelas. Bagian Lobi utama yang berada di tengah dan memilikki massa terbesar merupakan bagian yang memilikki hierarki tertinggi. Teori arsitektur indis muncul pada penerapannya yang mana bangunan penting atau bangunan publikharus memilikki tata massa, order, hierarki yang jelas yang melambangkan ketegasan, kekokohan.

Massa bangunan yang memanjang ini justru bentuk yang paling efisien karena harus menyediakan tempat naik turunnya penumpang sepanjang gerbong yang datang. Dari massayang panjang tersebut diperlukan satu tempat yang menerima kedatangan calon penumpang untuk membeli tiket sehingga perletakkan massa lobi yang ada di tengah menjadi efektif.

Dari denah dan bentuk fasad bangunan Stasiun Tawang kita dapat melihat penggunaan prinsip ordering principle dalam penataan stasiun Tawang, yaitu repetisi, datum, simetris dan aksis. Aksis sumbu imajiner terlihat menghubungkan 2 node, yaitu halaman depan dengan peron. Aksis ini menembus lobi utama tepat pada sumbu simetrisnya. Aksis dan simetris yang kuat memberikan kesan yang kokoh dan tegas. Repetisi terlihat pada atap yaitu dengan penataan skylight dan ventilasi atap dengan irama ABB-BBA. Atap yang mendominasi fasad menjadi datum yang menyatukan berbagai elemen fasad. Selain bentuk atap yang panjang, warna genteng juga turut menyatukan elemen-elemen fasad (Figur 7). 


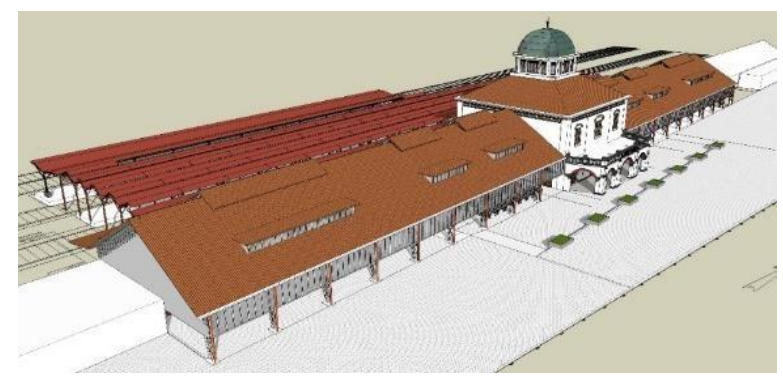

Figur 5. Aerial View Massa Bangunan Stasiun

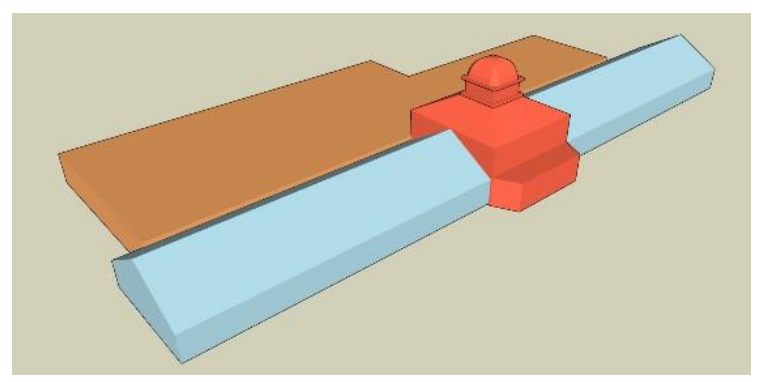

Figur 6. Analisis Bentuk Dasar Massa Stasiun

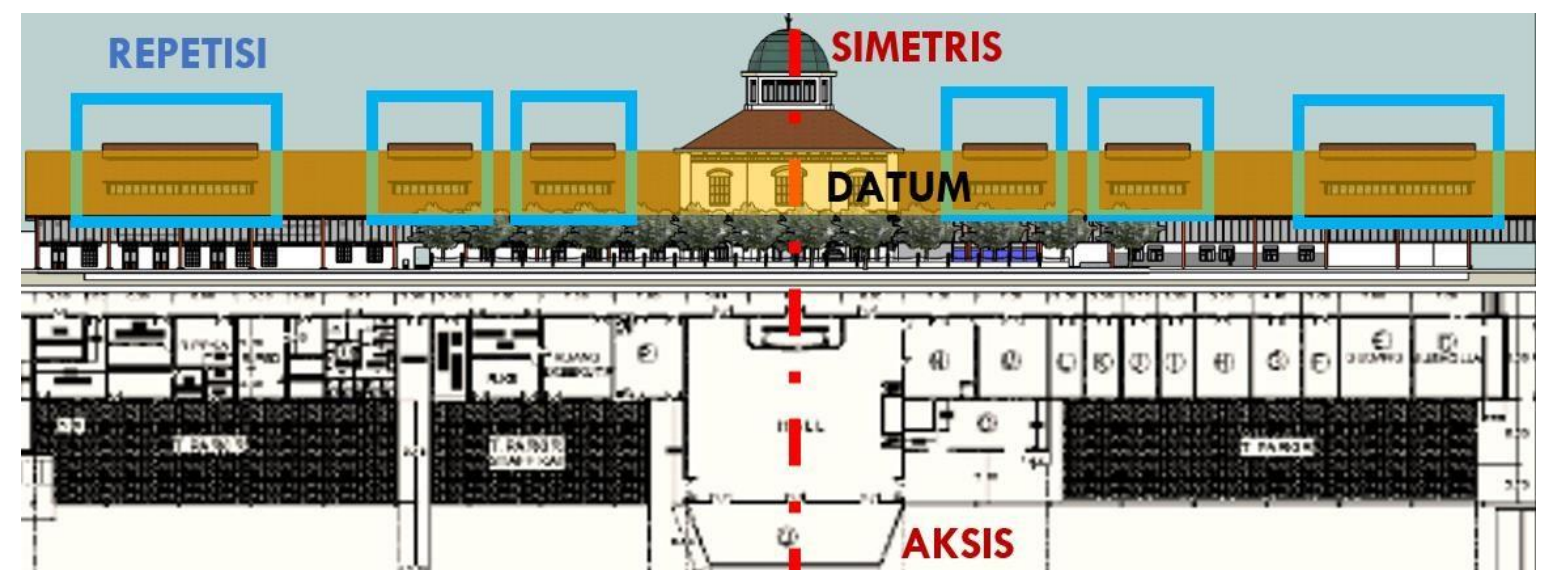

Figur 7. Ordering Principle pada Fasad dan Denah Stasiun

\subsubsection{KONFIGURASI RUANG}

Bangunan indis memilikki ruang yang simetris baik denah maupun fungsinya. Umumnya bangunan yang massanya simetris memilikki fungsi ruang yang simetris, misalnya bangunan kantor. Pada bangunan stasiun program ruang sudah ditentukan dan harus tercipta konfigurasi ruang yang baik agar tiap aktivitas dan alur kegiatan berjalan dengan baik. Menurut Triwinarto (1997) bangunan stasiun kereta api umumnya terdiri atas bagianbagian sebagai berikut: (1) Halaman depan: Ruang peralihan, biasanya difungsikan tempat parkir. (2) Bangunan Stasiun: berisi ruang-ruang untuk menjalankan fungsi stasiun, antara lain lobi, loket, administratif, operasional, area komersil, dan servis. (3) Peron: tempat menunggu kereta dan bongkar muat barang. (4) Emplasemen: Area ini termasuk peron dan jalur rel kereta api. (Figur 8.) 


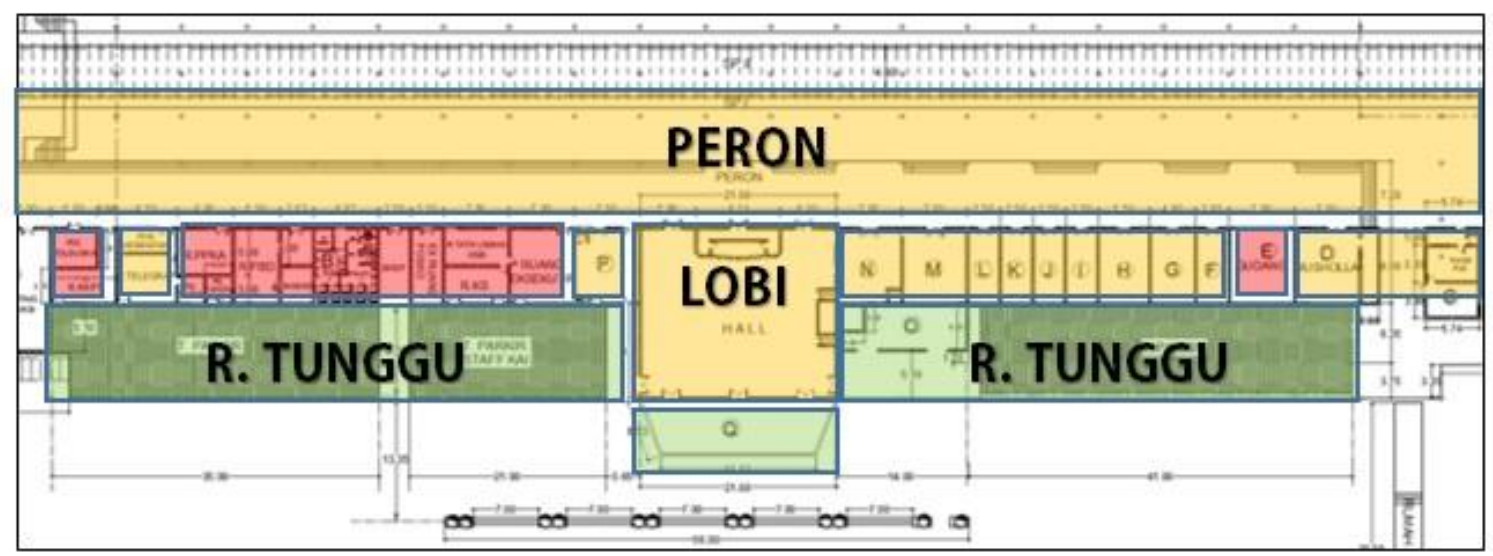

Hijau: publik Kuning: semi publik Merah: semi privat

Figur 8. Zonasi dan Konfigurasi Ruang Dalam Stasiun Tawang

Walaupun bangunan stasiun Tawang simetris secara bentuk, fungsi ruang dalam nya tidak simetris. Penataan denah sesuai dengan penataan massa bangunan. Umumnya bangunan kolonial simetris baik fungsi ruang maupun bentuk namun pada stasiun yang lebih dipentingkan adalah efisiensi ruang dan pencapaian. Lobi utama menjadi ruangan dengan luasan terbesar. Ruang lobi utama sebagai ruang penerima berhierarki paling tinggi harus representatif sehingga dibuat besar dan mewah. Hal ini sesuai dengan prinsip bangunan umum kolonial yang mewakili kemewahan dan kekuasaan.

Penyikapan tropis pada penataan ruang terlihat pada ruang yang ditata single-loaded dan adanya teras di sepanjang bagian depan dan belakang bangunan yang digunakan sebagai area sirkulasi dan ruang tunggu. Dengan penataan seperti ini memungkinkan terjadinya crossventilation dan cahaya matahari bisa menerangi ruangan dari kedua sisi (Figur 9 dan 10).

Seiring berkembangnya waktu berkembang pula kebutuhan pengguna stasiun yang harus diwadahi dalam program ruang yang lebih baik. Stasiun Tawang juga sudah mengalami berbagai perubahan. Perubahan yang terkait dengan konfigurasi ruang adalah area yang saat ini digunakan sebagai pertokoan. Pada tahun awal dibangun ruangan ini belum ada. Saat ini dinding pertokoan ini terlihat berbeda dengan dinding asli di sebelahnya. Hal ini sebenarnya menganggu karena terjadi perbedaan ekspresi dinding lama dan baru (Figur 11 dan 12). 


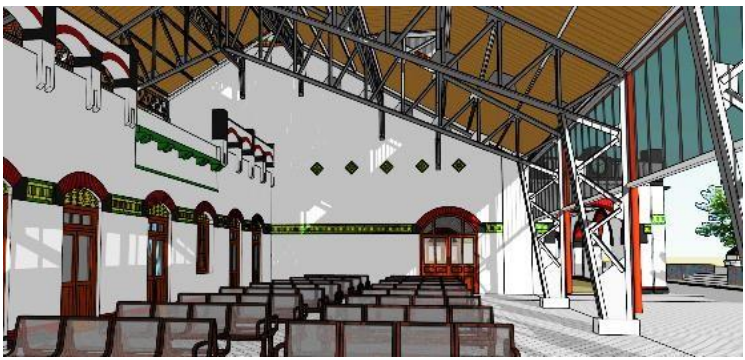

Figur 9. Teras Depan Stasiun Sebagai Ruang Tunggu

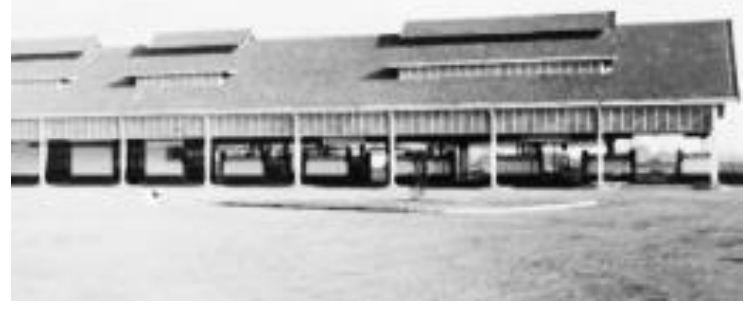

Figur 11. Pertokoan Belum Ada Tahun 1920

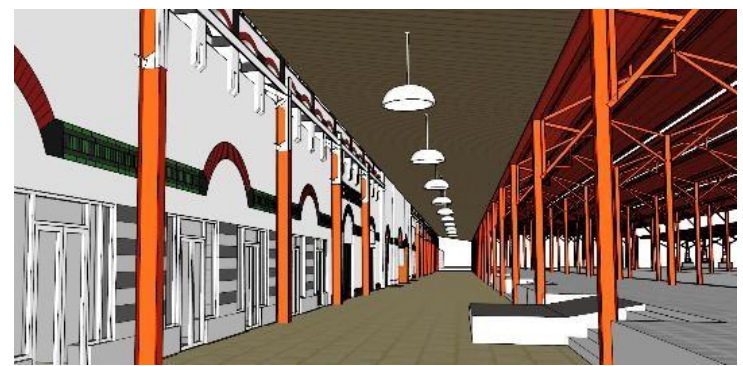

Figur 10. Teras Belakang Stasiun Sebagai Sirkulasi

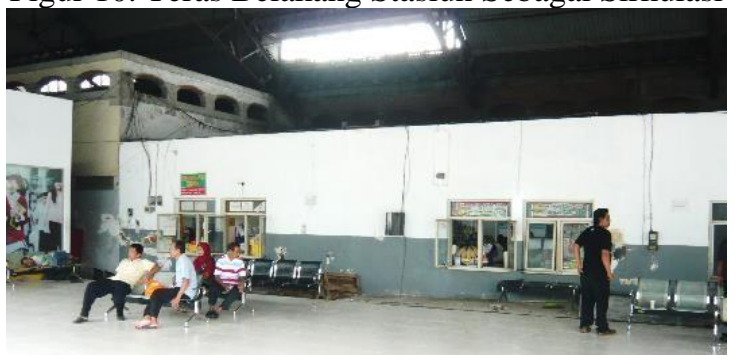

Figur 12. Dinding Pertokoan Baru Saat Ini

\subsubsection{ELEMEN ATAP BANGUNAN}

Pada arsitektur indis yang menyikapi iklim tropis muncul bentukan arsitektur yang didominasi oleh atap. Pada Stasiun Tawang atap mendominasi sebagian besar fasad Stasiun Tawang. Arsitektur di daerah tropis identik dengan bagian atapnya yang dominan dibanding bagian lainnya (Soekiman, 2011). Untuk menyikapi cuaca atap dibuat lebar dan besar. Di atap terdapat skylight untuk memasukkan cahaya matahari dan atap split yang berfungsi tempat pertukaran udara yang naik ke atap.

Atap lobi mendominasi fasad karena letaknya ditengah. Di ujung atap terdapat cupola yang berfungsi memasukkan cahaya dan udara alami ke bangunan (Figur 13). Cupola ini menggunakan rangka dan pentutup atap baja sedangkan penutup atap pada bagian bawahnya berupa genteng tanah liat. Cupola berukuran besar sehingga membutuhkan penopang kolom. Di ujung atap bawah terdapat overstek selebar 1meter yang melindungi kerawang agar hujan tidak tampias. Contoh aplikasi cupola juga ada pada museum Fatahillah Jakarta yang menggunakannya pada area pintu masuk di bagian tengah bangunan (Figur 14).

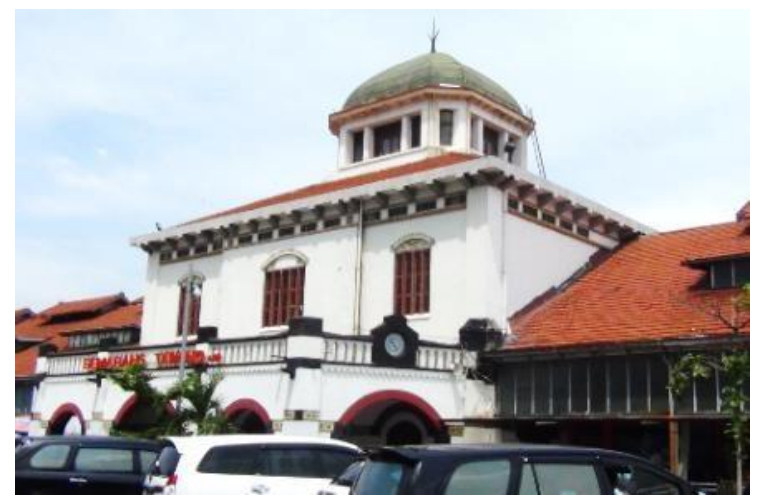

Figur 13. Cupola pada Stasiun Tawang

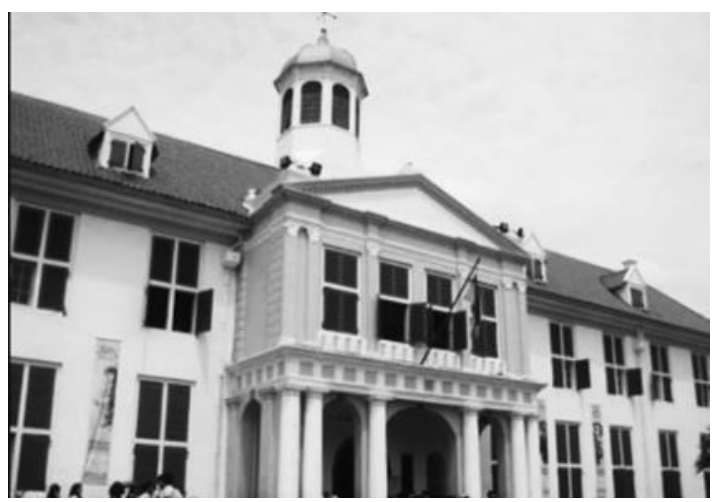

Figur 14. Cupola Pada Museum Fatahilah 
Atap disamping lobi berupa atap pelana. Struktur ini berupa kuda-kuda terbuat dari truss baja siku rangkap dengan paku keling (Figur 15). Atap pelana ini cukup besar sehingga mendominasi fasad bangunan. Pada beberapa bagian terdapat modifikasi pada struktur ini dengan menambahkan struktur untuk skylight dan lubang ventilasi atap di bubungan. Beberapa keunikan dari struktur atap ini adalah kuda-kuda terbuat dari truss baja siku rangkap dengan paku keling. Penutup atap menggunakan genteng tanah liat. Atap emplasemen menaungi peron dan tempat berhentinya kereta. Struktur atap menggunakan baja monobeam profil IWF. Jarak bebas dari tanah hingga atap cukup tinggi pada emplasemen karena harus mampu dilewati kereta api (Figur 16).

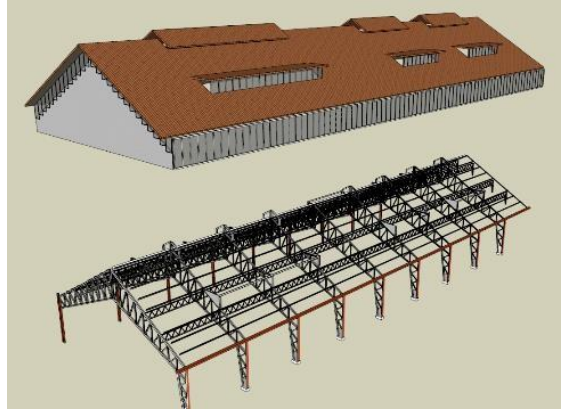

Figur 15. Struktur Portal Pada Atap Pelana

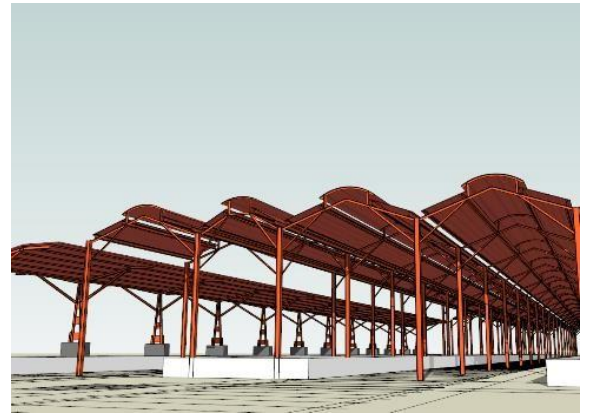

Figur 16. Atap Peron Stasiun Tawang

Dari penjabaran di atas dapat diketahui bahwa ada beragam tipe struktur atap dari yang sederhana hingga yang rumit. Dari penerapan itu kita dapat melihat bahwa ada hierarki dari penggunaan struktur. Bagian lobi yang memilikki hierarki tertinggi menggunakan struktur atap bertingkat dan kubah diatasnya. Hierarki yang lebih rendah berikutnya adalah atap pelana di samping lobi yang menggunakan truss baja. Sedangkan hierarki terendah ada pada atap peron yang menggunakan baja monobeam profil sederhana.

Plafon sebagai elemen nonstruktural atap juga memilikki beragam tipe sesuai dengan fungsi ruangannya. Plafon lobi utama sangat tinggi memberi kesan megah sekaligus memudahkan udara bersirkulasi dengan baik. Plafon ini menggunakan ornamen bercorak art deco (Figur 17). Di ruang kepala stasiun kita dapat melihat struktur penahan plafon berupa balok kayu. Di pengakhiran balok ada ornamen bercorak local (Figur 18). Plafon gipsum baru polos digunakan di ruangan lain yang fungsinya tidak terlalu penting dan diduga plafon awal sudah rusak sehingga diperbarui. Pada teras belakang plafon menggunakan lambrisering. Area ini sangat menunjukkan ciri khas arsitektur Indis baik dari plafon maupun ornamen lampu dan lainnya. Pemilihan elemen hiasan seperti lampu chandelier bercorak art nouveau juga mempertegas suasana indis. 


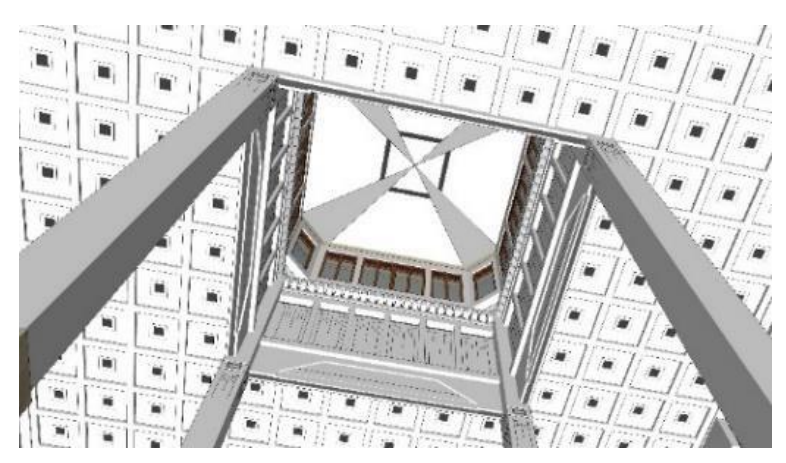

Figur 17. Plafon Lobi dengan corak Art-Deco

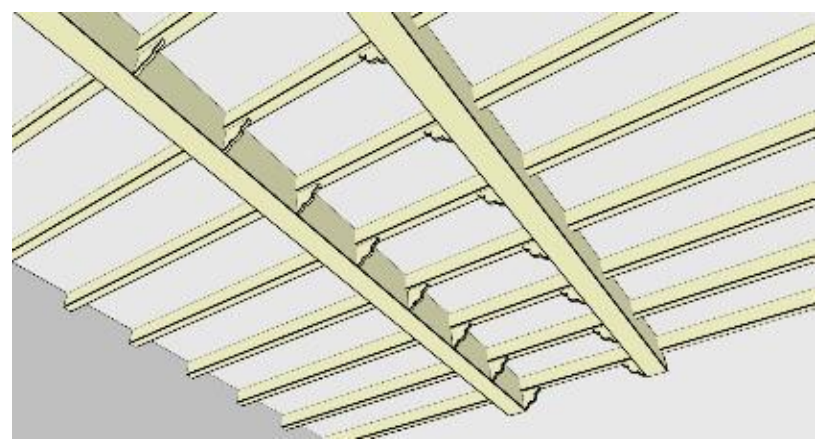

Figur 18. Plafon R. VVIP Bernuansa Lokal

Detil pada atap Stasiun Tawang bukan sekadar ornamental melainkan berfungsi dalam menyikapi iklim tropis lingkungan. Pada bangunan kolonial seringkali ditemukan desain dinding yang menjadi pengakhiran massa bangunan yang disebut sebagai gevel (dinding ampik) (Figur 19). Di pengakhiran atap pelana terdapat kaca es yang dipasang di gevel bagian atas. Kaca ini berfungsi untuk memasukkan cahaya matahari ke dalam bangunan. Namun pemasangan kaca ini dibuat per panel sehingga secara keseluruhan terlihat patahan-patahan miring (Figur 20). Penerapan kaca seperti ini juga ditemukan di stasiun NIS lainnya. Konstruksi penyangga kaca terbuat dari besi juga sehingga konstruksi penyambungan dengan struktur utamanya menjadi lebih mudah. Di puncak cupola juga terdapat hiasan kemuncak namun bentuknya sederhana yang diperkirakan sebagai penangkal petir.

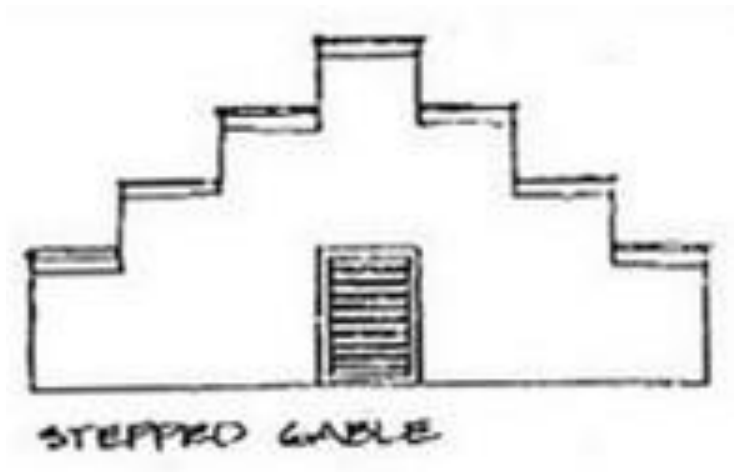

Figur 19. Varian Gevel Berundak

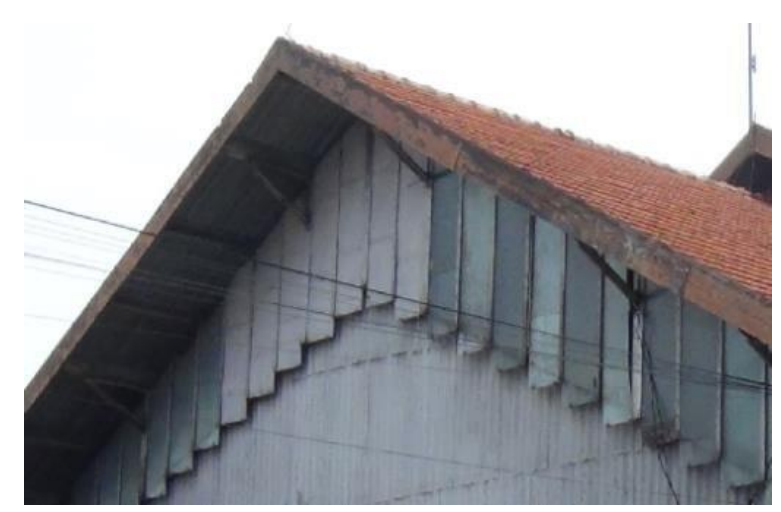

Figur 20. Gable Atap Stasiun Tawang

\subsubsection{ELEMEN BADAN BANGUNAN}

Elemen pelingkup vertikal erat kaitannya dengan aksesibilitas pengguna. Elemen struktural pada dinding meliputi kolom dan dinding pemikul. Seluruh dinding stasiun Tawang merupakan dinding pemikul dengan ketebalan minimal $30 \mathrm{~cm}$ dengan susunan satu bata karena harus menyalurkan beban ke tanah. Pada beberapa bagian yang menopang beban lebih diberikan penebalan hingga $50 \mathrm{~cm}$ untuk memperkuat (Figur 21). Pada bukaan pintu maupun jendela digunakan konstruksi bata rolaag. Selain sebagai elemen struktural ternyata rolaag ini juga menjadi elemen ragam hias dengan cara diberi warna merah dan hitam. Rolaag ini juga disambungkan dengan hiasan keramik glazur yang menerus sepanjang dinding (Figur 22). Sebagai respon terhadap iklim, pada bagian atas lobi dinding tidak terlindung atap sehingga dibuat bukaan, dan ragam hias seefisien mungkin. 


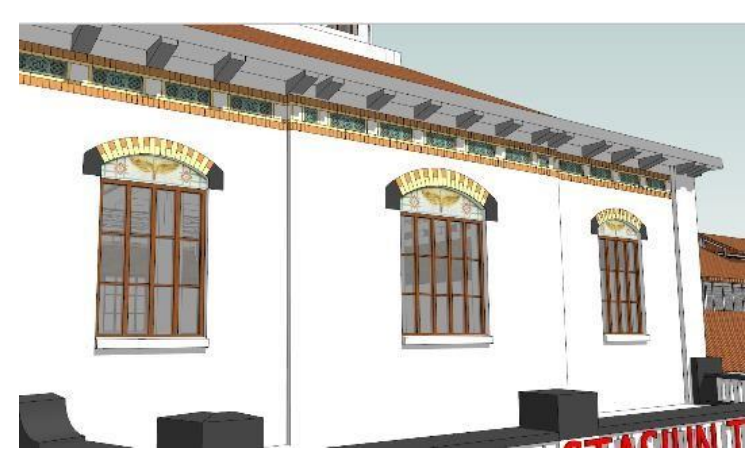

Figur 21.Ragam Hias Pada Fasad Lobi

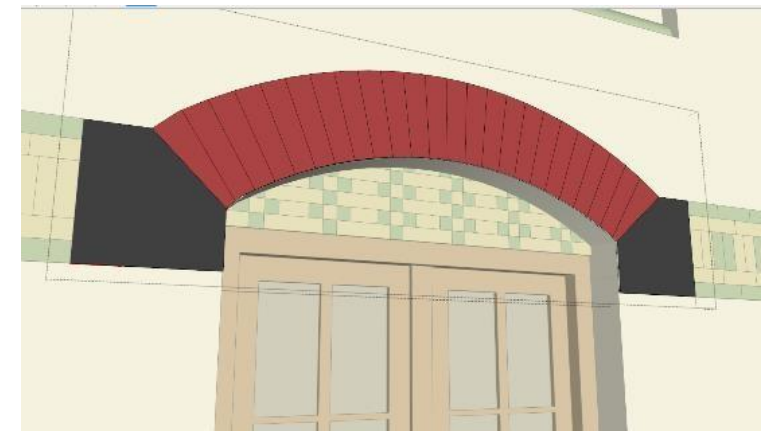

Figur 22. Kolom Baja di Stasiun Tawang

Kolom bata hanya terdapat pada lobi utama untuk menyokong atap kubah. Tidak adannya dinding pemikul di tengah ruangan lobi mengharuskan dibuat kolom-kolom dari bata. Walaupun terbuat dari bata ternyata kolom tersebut sanggup menahan atap (Figur 23). Kolom ini ternyata tidak dibuat dengan alasan fungsional saja. Jika dilihat empat kolom yang tinggi menjulang ini terlihat seperti tiang saka guru pada rumah joglo Jawa (Figur 24). Hal ini juga lah yang menjadi ciri khas Stasiun Semarang Tawang. Dengan ruang lobi yang berbentuk persegi, empat kolom ini berada persis di area tengah bangunan. Walaupun struktur atap nya tidak menerapkan sistem konstruksi atap Jawa, kita dapat mengetahui bahwa ada upaya dari sang arsitek untuk memasukkan unsur budaya lokal pada lobi utama ini. Kolom ini merupakan struktur atap yang menyangga cupola.

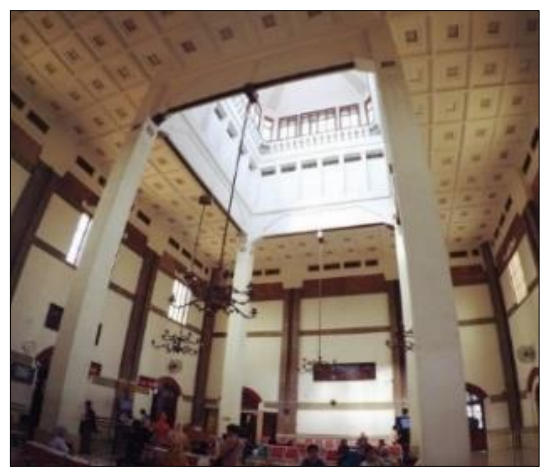

Figur 23. Kolom Lobi Utama Seperti Saka Guru

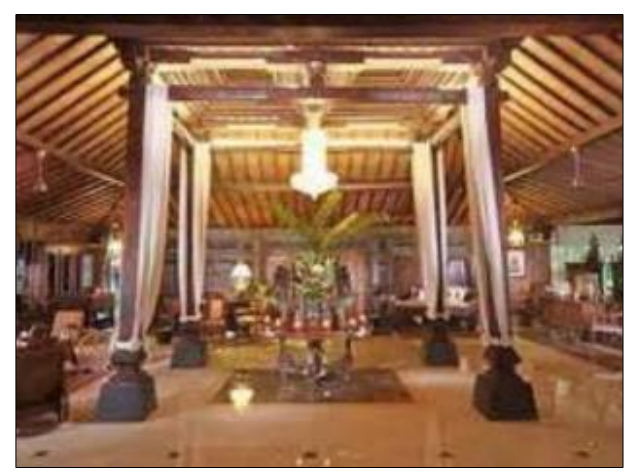

Figur 24. Saka Guru Pada Pendopo Joglo

Penggunaan baja menjadi pembeda terhadap tipologi bangunan kolonial lainnya. Selain itu konstruksi baja memilikki kelebihan antara lain konstruksinya yang tidak memakan waktu lama dan ringan. Sambungan baja-baja tersebut menggunakan paku keling karena belum ada konstruksi las (Figur 25). Konstruksi ini digunakan di Eropa pada masa itu sehingga menjadi sesuatu yang baru. Baja yang digunakan juga beragam mulai dari baja siku hingga baja rel (Figur 26). Karena bangunan stasiun perusahaan NISM yang memiliki banyak persediaan baja untuk rel kereta. 


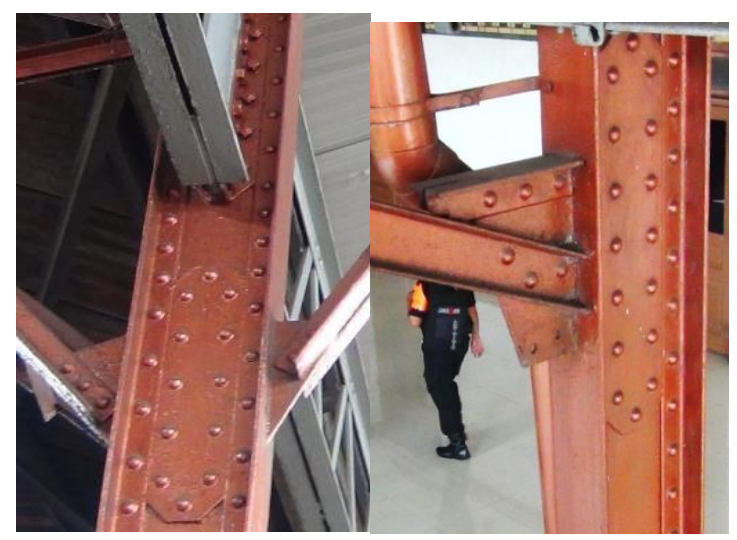

Figur 25. Kolom Baja dan Paku Keling

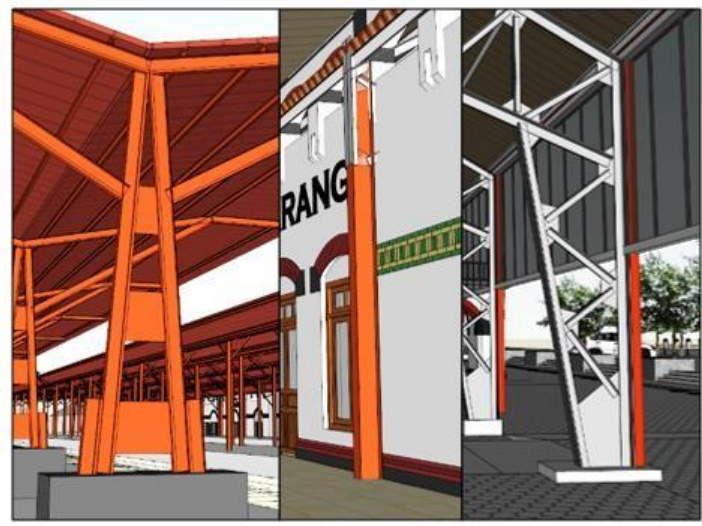

Figur 26. Ragam Kolom Baja

Umumnya dinding bangunan tropis selalu terlindung dari cuaca sehingga atap menjadi besar. Namun di negara Eropa dinding dibiarkan tak terlindung. Konsep arsitektur indis yang diterapkan di stasiun Tawang memadukan dua konsep tersebut. Dinding ruangruang fungsional kecil dilindungi dengan atap karena ada bukaan seperti pintu, jendela, dan ornamen lainnya. Sedangkan pada dinding massa lobi utama yang besar dibuat menonjol dan dominan sebagai ekspresi hierarki tertinggi pada stasiun Tawang.Pada dinding eksterior lobi utama tidak banyak terdapat ornamen melainkan hanya bukaan-bukaan fungsional seperti jendela kaca besar dan kerawang untuk ventilasi. (Soekiman, 2011)

Di Stasiun Semarang Tawang terdapat beragam tipe pintu dan jendela sebagai bentuk penyesuaian dengan kebutuhan dan karakter aktivitas di dalam ruangannya. Pintu dan jendela lobi berukuran besaruntuk memudahkan orang banyak keluar masuk bangunan. Pintu dan jendela ke ruang operasional berukuran lebih kecil dan menggunakan kaca sehingga dapat mengawasi kegiatan di peron dan lalu lintas kereta. Pintu area pertokoan menggunakan aluminium karena merupakan bagian bangunan yang lebih baru. Dari elemen pintu kita dapat mengetahui bahwa hiraki tertinggi ada pada area lobi utama. (Figur 27)
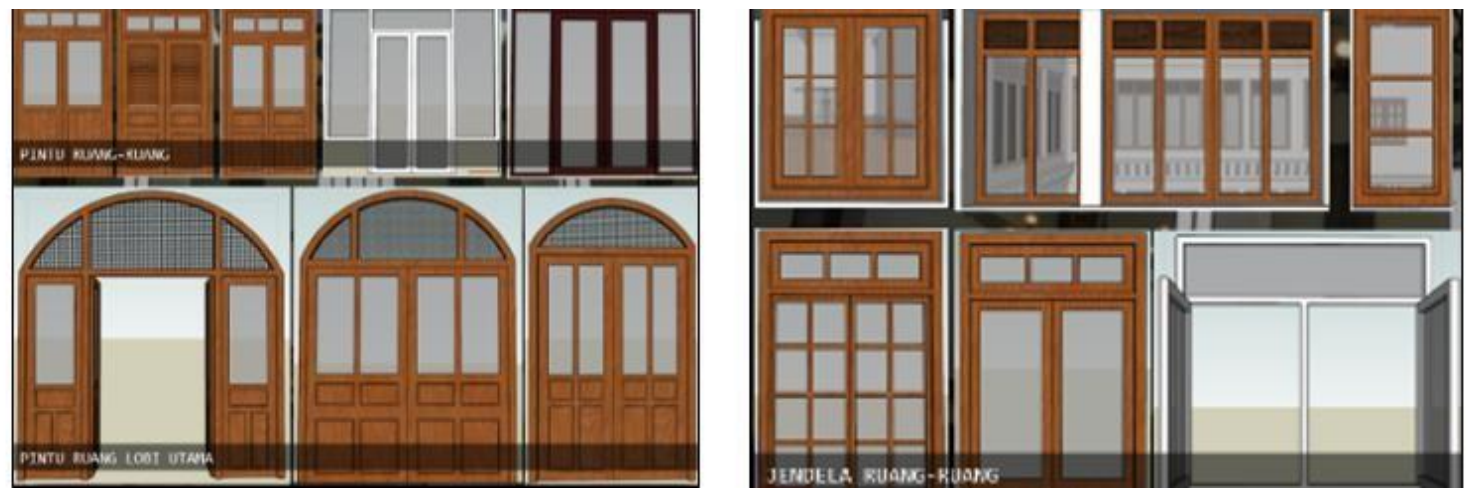

Figur 27. Ragam Pintu dan Jendela Pada Stasiun Tawang

Dinding bangunan memiliki beberapa ornamen layaknya bangunan indis. Karakter ornamen ini sebenarnya banyak juga dipakai di bangunan stasiun lain. Ornamen pada dinding banyak berperan sebagai hiasan dinding (Figur 28). Biasanya dalam ornamen perancang dapat memunculkan suasana budaya karena motif ragam hias ini banyak diadaptasi dari budaya yang 
bersangkutan. Di tengah tinggi dinding terdapat ornamen dari keramik glazur berwarna yang ada di sepanjang dinding. Pola warna yang diterapkan sederhana (Figur 29).

Ornamen ini berperan sebagai datum untuk memberikan "kesatuan" antar pintu, jendela, dan dinding. Pada bagian atas dinding terdapat ornamen balustrade di atas dinding.

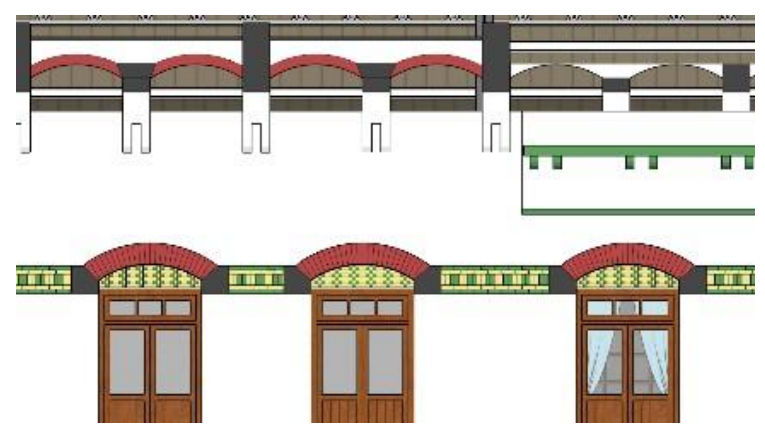

Figur 28. Hiasan Dinding Stasiun

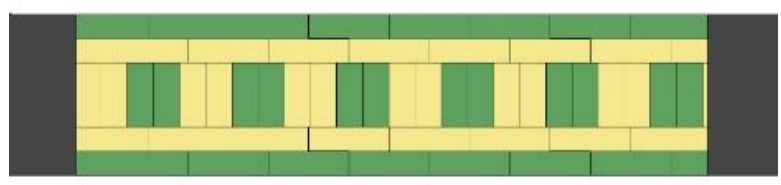

Figur 29. Pola Keramik Glazur Corak Art-Deco

Pada bangunan indis seringkali ditemukan simbol-simbol ornamen yang bertujuan memberikan identitas pada bangunan tersebut dan informasi bagi orang yang melihat. Pada dinding luar lobi terdapat mural bergambar roda bersayap (Figur 30) dan karya seni perunggu bergambar serupa di dalam lobi (Figur 31) Gambar ini merupakan lambang perusahaan kereta api Belanda NISM pada masa itu. Di beberapa stasiun di daerah Semarang juga terdapat simbol serupa yang menjadi identitas bangunan ini (PT Kereta Api Indonesia, 2012).

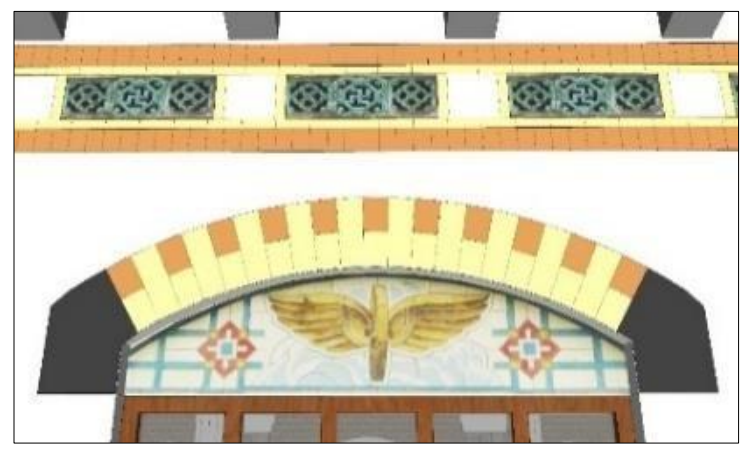

Figur 30.Mural NIS Pada Fasad Lobi

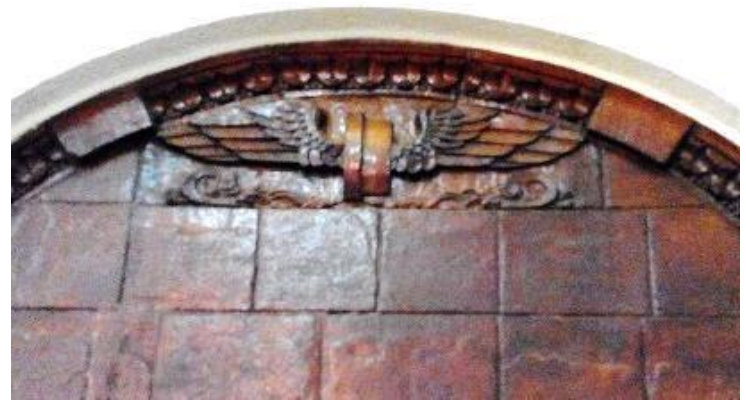

Figur 31. Karya Seni pada Interior Lobi

\subsubsection{ELEMEN LANTAI BANGUNAN}

Di bagian bawah bangunan terdapat elemen struktural seperti pedestal. Pedestal yang dapat terlihat hanya sebagian karena beberapa sudah tertutup lantai baru. Saat ini hanya ada satu macam pedestal beton berbentuk kubus sederhana. Bagian yang menarik adalah sambungan ujung bawah baja pada betonnya. Karena kolomnya baja maka desain sambungan memilikki keindahan tersendiri (Figur 32 dan 33) 


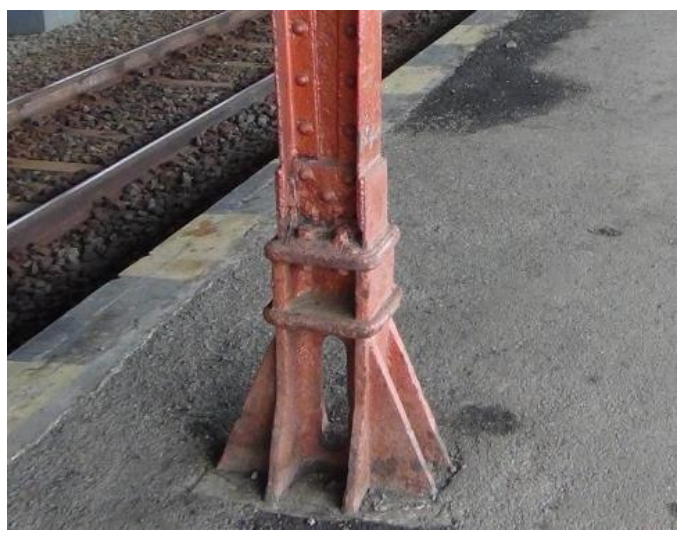

Figur 32. Pedestal Baja Asli Pada Peron

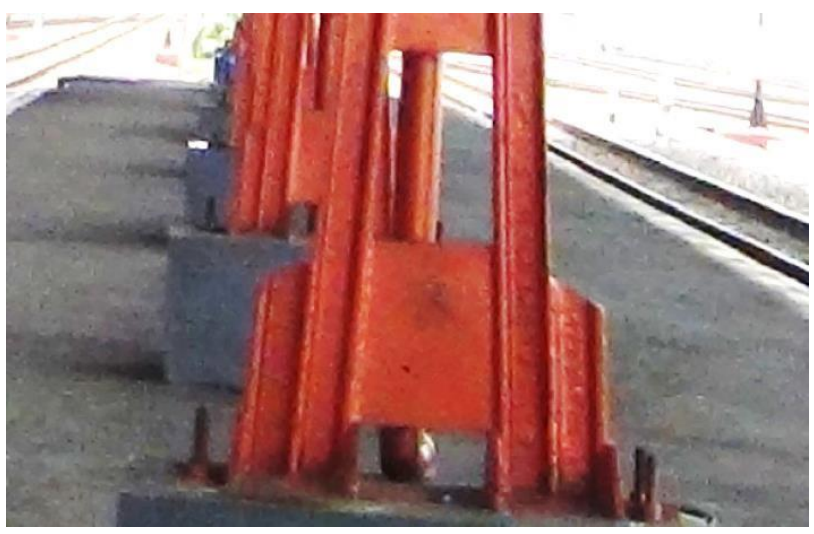

Figur 33. Pedestal Beton Kolom Baja Peron

Pada bagian peron lantai mengalami peninggian. Lobi sebagai ruang yang representatif beralaskan homogenous tile. Warna tile yang digunakan adalah warna muda agar pengunjung lebih fokus ke kemegahan plafon ruang. Pola lantai memberikan aksis yang jelas dari depan ke belakang (Figur 34). Teras belakang juga mengggunakan homogenous tile. Pada lantai yang mengalami renovasi penerapan konsep arsitektur indis sudah hilang. Yang terlihathanya pada material yang sekarang. Konsep penyikapan tropis justru masih terlihat pada ruang teras depan stasiun yang masih menggunakan paving blok. Material ini tidak licin saat ada air dan mudah diperbaiki karena tidak permanen (Figur 35).

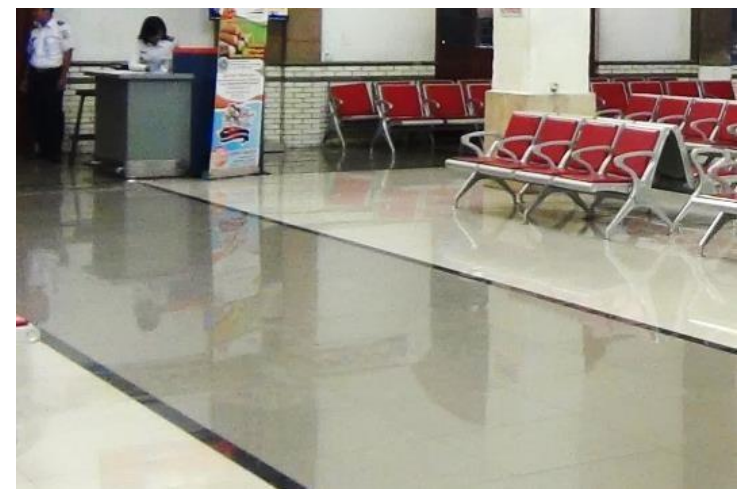

Figur 34. Lantai Lobi Dari Homogenous Tile

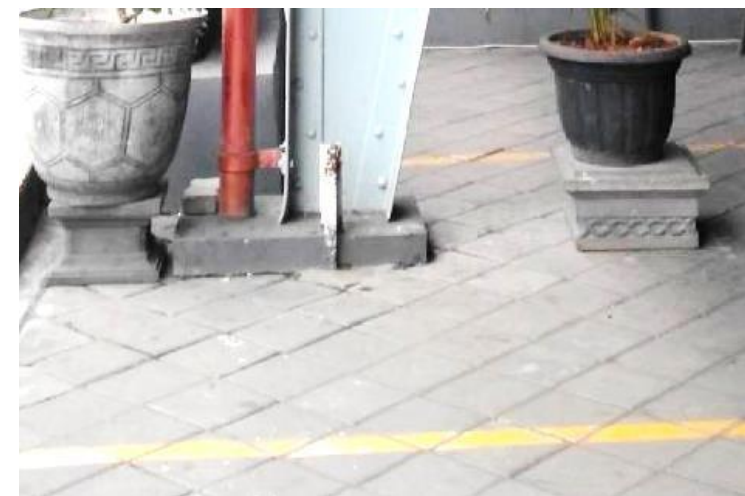

Figur 35. Lantai Teras Depan Dari Paving Blok

\subsection{PENGARUH FUNGSI, BENTUK, STRUKTUR TERHADAP HIERARKI RUANG PADA STASIUN TAWANG}

Hierarki fungsi dapat dilihat dari dua sisi, yaitu dari fungsi sebagai stasiun dan status pengguna ruang. Sebagai stasiun penumpang maka hierarki teratas ada pada pelayanan penumpang dari datang hingga naik ke kereta. Jika dilihat dari fungsinya maka hierarki tertinggi ada pada peron, lalu ruang tunggu, dan loket tiket. Berikutnya ada pada kegiatan operasional stasiun seperti ruang PPKA, ruang medis, dan ruang polsuska karena fungsinya menjaga lancarnya kegiatan di stasiun dan kereta api. Hierarki berikutnya ada pada ruang administrasi yang meliputi Ruang kepala stasiun. Area ini berisi pejabat stasiun yang mengatur dan mengawasi jalannya kegiatan di stasiun. Hierarki berikutnya ada pada area komersil yang 
merupakan fasilitas penunjang. Hierarki terendah ada pada area servis. Hierarki juga bisa dilihat dari status pengguna ruangnya.

Dari penjabaran analisis di atas dapat terlihat pengaruh fungsi, bentuk, dan struktur terhadap hierarki ruang Stasiun Tawang. Sebenarnya bangunan stasiun sudah memilikki hierarki fungsi yang menentukan perletakkan ruang dalam stasiun namun jika dilihat dari ornamen elemen pelingkupnya didapati beberapa ketidak cocokan, misalnya hierarki antara peron dan lobi utama. Walaupun hierarki fungsi tertinggi ada pada peron, arsitek menempatkan lobi utama sebagai hierarki tertinggi karena mengacu pada status jabatan penggunanya (Figur 36). Hierarki berikutnya ada pada peron. Peron yang hanya bisa diakses pengunjung penumpang kereta memilikki fasilitas yang lebih lengkap dibanding teras depan. Area ini memilikki elemen pelingkup yang lebih lengkap yaitu adanya plafon dan lampu hias pada bagian atas ruang yang mana tidak ditemukan pada teras depan.
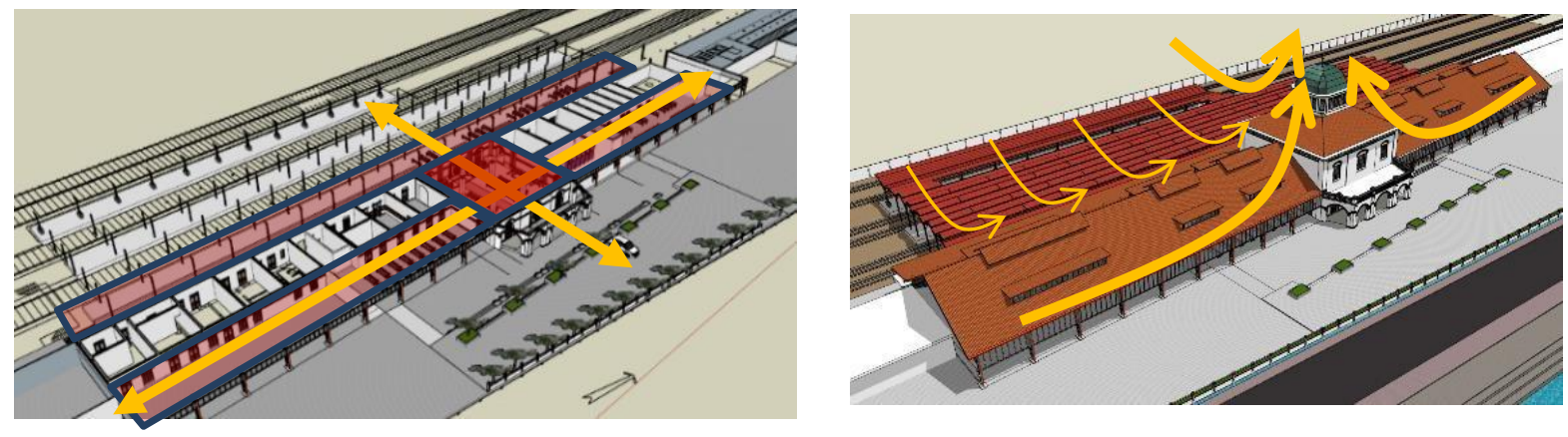

Figur 36. Hierarki Tinggi ada Pada Area Tengah Stasiun

Hierarki berikutnya adalah teras depan. Di area ini bisa diakses oleh semua orang sehingga kadang menjadi kurang nyaman dan ramai. Area tunggu I di sisi yang dekat pintu keluar lebih tinggi hierarki nya dibanding area tunggu II di sisi lain teras depan. Hal ini terlihat dari elemen dinding yang masih asli pada area I sehingga terasa suasana arsitektur indisnya. Hierarki berikutnya ada pada loket. Loket ini menempati ruang yang kecil dan tidak terdesain dari awal. Ruang ini disesuaikan dengan semakin sedikitnya penumpang yang beli langsung tiket di stasiun sehingga tidak memerlukan ruang yang besar.

Hierarki berikutnya ada pada ruang administratif pejabat stasiun. Ruang ini berada dekat dengan area pelayanan penumpang, sesuai dengan hierarkinya. Kedua klasifikasi ruang ini bertemu di pertemuan Ruang VVIP dengan ruang KS, satu untuk penumpang dengan kelas tertinggi, satunya untuk pejabat dengan kelas tertinggi. Pentingnya ruangan kepala stasiun ini terlihat dari pemilihan elemen pelingkupnya yang masih mempertahankan elemen asli, misal plafon, panel dinding, dan pintu jalusi yang tidak ditemukan di ruang lainnya.

Hierarki berikutnya ada pada ruang operasional yang diletakkan berdampingan dengan ruang administrasi untuk memudahkan koordinasi kegiatan. Pada ruang-ruang ini sudah semakin sedikit ornamen pelingkup yang masih asli. Plafon, dinding, lantai sudah diganti atau ditutup dengan material baru.

Area komersil sebenarnya agak tersebar di beberapa tempat namun paling banyak ada di timur laut lobi utama. Area ini letaknya bersebrangan dari area operasional. Seusai dengan hierarkinya area komersil ini mayoritas sudah menggunakan dinding, pintu, dan jendela baru. 
Bahkan deretan pertokoan awalnya tidak ada pada desain namun ditambahkan untuk menambah pelayanan pengunjung. Secara fungsi dan status penggunanya area ini memang hanya sebagai fasilitas penunjang.

Hierarki terendah ada pada area servis, yaitu toilet dan gudang, ruangan yang tidak ditonjolkan secara visual dan penempatan. Ukuran, bentuk, dan lokasi tidak menonjol namun demikian tetap berada di area yang mudah dicapai. Walaupun demikian di toilet lama stasiun merupakan ruang yang didesain dengan baik karena bagi sang arsitek ruang ini juga digunakan oleh semua orang termasuk pengunjung sehingga menggunakan jendela yang didesain khusus dengan ukuran sempit untuk membatasi akses visual namun cahaya dan udaratetap masuk (Figur 37).
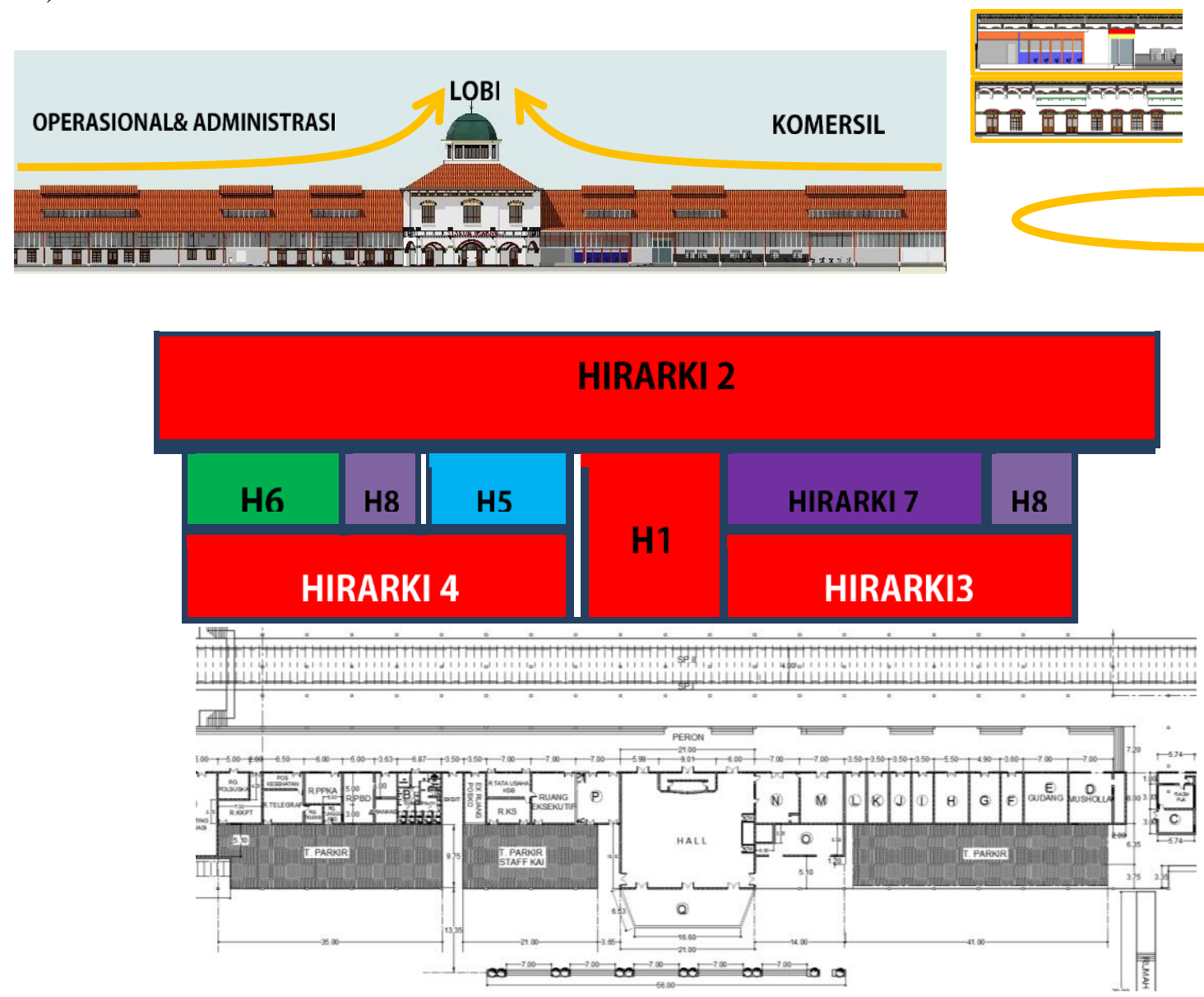

Merah: utama---Hijau: Operasional---Biru: Administratif---Ungu: KomersilKuning: Servis Hierarki tertinggi ada di tengah stasiun dengan bentuk dan ukuran ruang berbeda dengan yang lain. Hierarki terendah ada di sisi tepi bangunan dengan ruang yang lebih kecil.

Figur 37. Urutan Hierarki Ruang Pada Stasiun Tawang

\section{PENUTUP}

Dari penelitian didapati bahwa arsitektur indis adalah hasil dari kebudayaan indis yang pernah berlangsung pada masa kolonial di Indonesia. Arsitektur indis menggunakan prinsip desain yang diadaptasi dari konsep arsitektur klasik Eropa namun tetap melakukan penyesuaian 
terhadap konteks lokal. Pada fungsi bangunan yang baru dibawa ke Indonesia seperti stasiun kereta api, penyesuaian pada desain lebih dominan pada penyikapan iklim tropis karena belum ada budaya lokal yang sesuai dengan fungsi bangunan tersebut. Konsep budaya lokal bisa muncul namun sebatas kesan-kesan semu agar familiar bagi masyarakat setempat. Bentukan dari arsitektur indis mengikuti pola-pola yang sudah ada, misalnya bangunan stasiun maka massa bangunan pasti linear memanjang mengikuti arah rel kereta. Stasiun Tawang menerapkan konsep arsitektur Indis hampir di seluruh bagian bangunannya. Penerapan konsep ini dilakukan mulai dari peletakkan bangunan di kawasannya di lokasi yang strategis. Bangunan terletak di tengah tapak yang cukup luas. Massa bangunan stasiun memanjang mengikuti arah rel kereta. Massa bangunan dibiarkan tetap sederhana untuk mencegah banyak detail bangunan yang tidak perlu agar perawatan mudah karena semakin banyak lengkungan pada bangunan semakin berisiko bocor saat hujan. Ruang dalam bangunan juga ditata mengikuti prinsip arsitektur indis. Bangunan Stasiun Tawang menggunakan prinsip penataan ruang single-loaded. Ruang dalam berada di tengah bangunan dan diapit oleh teras depan dan belakang. Teras tersebut dimanfaatkan sebagai ruang tunggu dan sirkulasi yang dilalui banyak orang sehingga dengan ruangnya yang besar tanpa plafon memudahkan sirkulasi udara.

Pada tiap bagian elemen pelingkup bangunan elemen atap merupakan bagian terpenting untuk menyikapi iklim tropis. Atap mendominasi seluruh fasad stasiun. Pada atap pelana terdapat skylight dan lubang angin di puncap atap untuk memasukkan cahaya dan udara alami. Plafon bangunan juga menunjukkan ciri arsitektur Indis dari penggunaan motif dan hiasannya.

Badan bangunan merupakan elemen bangunan dengan ornamen terbanyak. Elemen struktural menggunakan dinding pemikul $30 \mathrm{~cm}$ dan kolom bata dan baja. Pintu dan jendela menggunakan kaca untuk memasukkan cahaya alami. Terdapat pula pintu jalusi yang menjadi ciri arsitektur indis. Di bagian atas pintu dan jendela menggunakan bovenlicht yang bisa dibuka sehingga dapat memasukkan cahaya dan udara alami. Sebagian besar elemen juga serupa dengan yang digunakan pada stasiun Tawang, misalnya penggunaan bata klinker untuk ornamen dan balustrade di bagian atas dinding.

Bagian lantai bangunan sudah kehilangan ciri arsitektur indis nya karena sudah mengalami renovasi. Lantai lama bangunan sudah tertimbun dan lantai yang baru menggunakan ceramic tile dan homogenous tile.

Ruang terwujud karena adanya elemen pelingkup yang mendefinisikan ruang tersebut. Elemen tersebut bisa berupa pelingkup atas (atap), pelingkup samping (dinding), dan pelingkup bawah (lantai). Elemen ini terbentuk dari fungsi, massa bangunan, dan struktur konstruksi. Penerapan ketiga aspek yang berbeda ini menjadi "ornamentasi" yang membentuk hierarki sebuah ruangan.

Konsep hierarki merupakan salah satu konsep ordering principle yang diterapkan dalam berbagai langgam arsitektur, termasuk di Eropa dan Jawa. Segala aspek dalam desain dapat menentukan hierarki ruang. Fungsi bangunan tercermin dalam penataan ruang dalamnya. Ruang yang tertata dengan baik akan membentuk hierarki yang runtut mulai dari ruang yang paling mencerminkan Stasiun Tawang hingga ke ruang-ruang servis.

Hierarki fungsi berdasarkan status jabatan pengguna ruang menjadi faktor dominan dibanding hierarki berdasarkan fungsi stasiun. Hierarki ini dapat kita lihat dari bentukan ruang nya dan elemen pelingkupnya. Misalnya pada lobi utama. Lobi utama menempati hierarki fungsi tertinggi dan diwujudkan dalam bentuk ruang yang berbeda dengan ruang lain dan struktur cupola. 
Hierarki diwujudkan dengan ukuran, bentuk, dan perletakkan elemen yang unik. Ornamen pada elemen pelingkupnya juga paling banyak, asli, dan menggunakan material terbaik. Bahkan adanya penerapan struktur empat kolom yang menyerupai saka guru untuk menyangga cupola menunjukkan bahwa ada upaya untuk memasukkan makna simbolis konsep Jawa pada ruang ini oleh arsitek.

Dari penelitian yang sudah dilakukan terlihat bahwa konsep arsitektur Indis cukup kuat pada Stasiun Semarang Tawang, tidak hanya elemen yang terlihat saja tetapi juga penciptaan ruang-ruang. Sebenarnya bangunan ini memilikki potensi menjadi contoh penerapan arsitektur Indis yang baik namun terkendala masih minimnya perhatian dari pihak pemilik, yaitu PT. KAI untuk mengangkat kembali nilai-nilai arsitektur indisnya.

Tidak semua bangunan lama harus diubah menjadi modern untuk menyesuaikan perkembangan jaman apalagi Stasiun Tawang sudah berstatus bangunan cagar budaya. Saat ini sudah banyak bangunan kolonial yang diubah menjadi museum. Ini menandakan masyarakat juga tertarik untuk datang ke bangunan lama. Akan lebih baik bila ada upaya untuk mengembalikan karakter arsitektur Indis pada Stasiun Semarang Tawang. Dengan demikian justru akan menambah daya tarik yang dimiliki Stasiun Tawang. Stasiun Tawang merupakan gerbang masuk bagi para turis domestik maupun mancanegara yang akan berlibur di kawasan kotalama sehingga sebaiknya stasiun juga ikut merepresentasikan keindahan arsitektur indis dari kawasan kota lama.

\section{DAFTAR PUSTAKA}

\section{Jurnal:}

Hartono, Samuel dan Handinoto. (2006). Arsitektur Transisi di Nusantara Dari Akhir Abad 19 ke Awal Abad 20. Dimensi Teknik Arsitektur, Vol. 34 No. 2, 81-92. Surabaya: Universitas Kristen Petra.

Indotek Engineering. 2010. Laporan Teknis Stasiun Semarang Tawang. Highest and Best Use Vol.2. Laporan Penelitian tidak diterbitkan. Jakarta: PT Kereta Api Indonesia.

Purwanto, L. M. F. (2005). Kota Kolonial Lama Semarang. Dimensi Teknik Arsitektur, Vol. 33 No.1, 2733. Surabaya: Universitas Kristen Petra.

Purwanto, Edi. (2008). Kajian Arsitektural Stasiun NIS. Jurnal Ilmiah Perancangan Kota dan Permukiman, Vol. 7 No.2.

Stephenson, M. (2000). Development and Validation of the Stephenson Multigroup Acculturation Scale. Physcological Assesment, Vol 12, 77-88.

Triwinarto S, Joko. (1997). Morfologi Arsitektural Stasiun Kereta Api Tawang, Semarang. Jurnal Teknik Universitas Brawijaya Malang. 


\section{Buku:}

Ching, D. K. (1979). Form, Space and Order. New York: Van Nostrand Reinhold Company.

Dakung, S. (1982). Arsitektur Tradisional Daerah Istimewa Yogyakarta. Yogyakarta: Departemen Pendidikan dan Kebudayaan.

De Jong, V. B. M. (1993). Spoorwegstations op Java. Amsterdam: De Bataafsche Leeuw.

Kartodirjo, S. (1990). Sejarah Pergerakan Nasional Jilid II. Jakarta: PT Garmedia.

Kartono, J. L. (2005). Konsep Ruang Tradisional Jawa Dalam Konteks Budaya. Dimensi Interior, p. 124136.

Koentjaraningrat. (1978). Pengantar Antropologi. Jakarta: Aksara Baru.

Kroeber, A. L. (1952). Anthtopology Today. Chicago: University of Chicago Press.

PT Kereta Api Indonesia (Persero), (2012). Bangunan Kereta Api Bersejarah. Jakarta: PT Kereta Api Indonesia (Persero).

PT Kereta Api Indonesia (Persero), (2012). The Beauty of Indonesian Railways. Jakarta: PT Kereta Api Indonesia (Persero).

Salura, Purnama. (2010). Arsitektur yang Membodohkan. Bandung: CSS Publishing.

Soekiman, D. (2011). Kebudayaan Indis: Dari Zaman Kompeni sampai Revolusi. Jakarta: Komunitas Bambu.

Thiis-Evensen, T. (1987). Archetypes in Architecture. New York: Oxford.

\section{Skripsi, Tesis, Disertasi}

Fauzy, Bachtiar. (2013). Ringkasan Disertasi Dinamika Relasi Makna, Fungsi, dan Bentuk Arsitektur Rumah Tinggal Masyarakat Pesisir.

Partono, Tri. (2010). Manifestasi Budaya Indis Dalam Arsitektur dan Tata Kota Semarang Pada Tahun 1900-1950. Skripsi tidak diterbitkan. Surakarta: Universitas Negeri Sebelas Maret.

\section{Internet}

Arsitektur Jawa; Ayu. Ayom, dan Ayem. (2012). Retrieved March 10, 2016, from https://iwanarsitekkidal.wordpress.com/2012/04/07/arsitektur-jawa/

Kota Lama Semarang (n.d.) Retrieved March 20, 2016, from: https://id.wikipedia.org/wiki/Kota_Lama_Semarang

PT Kereta Api Indonesia (persero) Unit Station Maintenance, Preservation, \& Architecture, (2016). Stasiun Semarang Tawang Semarang. Retrieved March 15, 2016, from http://heritage.keretaapi.co.id/?p=4627 